\title{
Model Matematik Awal Optimasi Lahan Pertanian
}

\author{
James Uriel Livingstone Mangobi ${ }^{1}$ \\ Universitas Negeri Manado \\ e-mail: jamesmangobi@unima.ac.id \\ Santje Matulende Salajang ${ }^{2}$ \\ Universitas Negeri Manado \\ Oltje Telly Sambuaga ${ }^{3}$ \\ Universitas Negeri Manado
}

\begin{abstract}
ABSTRAK
Petani sering dihadapkan dengan berbagai kendala yang mendasar dalam upaya meningkatkan hasil pertanian mereka, akibatnya hasil pertanian yang mereka panen tidak optimal. Adapun kendala-kendala tersebut, antara lain: kebingungan dalam memilih jenis tanaman yang akan ditanam, pengalokasian lahan yang sesuai dengan tanaman yang mereka tanam, karena tanaman yang dipilih tidak hanya satu jenis saja, maka penempatan dan luas lahan untuk tanaman-tanaman tersebut harus bisa mencapai hasil dan laba yang optimal, dan jumlah hasil panen yang sedikit sehingga mendapatkan laba yang sedikit pula. Untuk mengatasi kendalakendala yang sering dialami oleh petani, bidang matematika melalui Linear Programming (LP) dipastikan dapat memberikan solusi yang tepat. Penulis memfokuskan penelitian ini pada lahan pertanian di Desa Sinsingon, Kecamatan Passi Timur, Kabupaten Bolaang Mongondow, Provinsi Sulawesi Utara $\left(0^{\circ} 48^{\prime} \mathrm{N} 124^{\circ} 24^{\prime} \mathrm{E}\right)$. Tujuan penelitian ini ialah merumuskan dan menyusun model matematik optimasi penggunaan lahan pertanian. Hasil penelitian menunjukkan bahwa model awal dapat dirumuskan dan disusun berdasarkan Model Linear Programming (LP) dengan data-data masukannya ialah ketersediaan air, ketersediaan bibit tanaman, ketersediaan pupuk, ketersediaan obat-obatan, luas lahan dan jenis tanaman yang akan ditanam.
\end{abstract}

Kata kunci: model matematik, optimisasi, pemrograman linear, lahan pertanian

\section{ABSTRACT}

Farmers are often confronted with various fundamental constraints in their efforts to improve their agricultural output, which in turn made their harvest yield cannot be optimized. The constraints such as: confusion in choosing the type of plant to be planted, the allocation of land in accordance with the plants they plant, because the selected plants are not just one type only, then the placement and the area of land for these crops should be able to achieve optimal results and earnings, and a small amount of crops that generate little profit. To overcome the constraints often experienced by farmers, the field of mathematics through Linear Programming $(L P)$ certainly can provide 6 right solution. The authors focused this research on agricultural land in Sinsingon Village, East Passi District, Bolaang Mongondow District, North Sulawesi Province $\left(0^{\circ} 48^{\prime} \mathrm{N} 124^{\circ} 24^{\prime} \mathrm{E}\right)$. The purpose of this research is to formulate and to develop mathematical models of agricultural land use optimization. The results showed that the initial model can be formulated and compiled based on Linear Programming Model (LP) with input data are water availability, availability of seeds, availability of fertilizer, availability of medicines, land area and types of plants to be cultivated.

Keywords: mathematical models, optimization, linear programming, agricultural land

Jurnal Frontiers Volume 1 Nomor 1, April 201839

P-ISSN: 2621-0991 E-ISSN: 2621-1009 


\section{PENDAHULUAN}

Bagian Sebagai negara agraris, Indonesia seharusnya mampu mengandalkan hasil pertanian sebagai komoditi utama di negara ini. Melalui pemerintah sekarang ini, pengembangan usaha pertanian yang menjadikan hasil pertanian sebagai komoditi utama perlu mendapat perhatian khusus dari berbagai instansi terkait, termasuk perguruan tinggi. Hasil pertanian sebagai komoditi utama dapat dilakukan melalui usaha intensifikasi, ekstensifikasi, diversifikasi dan rehabilitasi secara terpadu. Usaha-usaha tersebut terkait dengan beberapa variabel, seperti bibit yang digunakan, pengairan, pemupukan, budidaya tanaman, proteksi tanaman dan lain-lain. Variabel-variabel tersebut masing-masing mempunyai kendalakendala yang mempengaruhi pengadaannya (Darmajana, 1987).

Petani sering dihadapkan dengan berbagai kendala yang mendasar dalam upaya meningkatkan hasil pertanian mereka, akibatnya hasil pertanian yang mereka panen tidak optimal. Adapun kendala-kendala tersebut, antara lain: kebingungan dalam memilih jenis tanaman yang akan ditanam, pengalokasian lahan yang sesuai dengan tanaman yang mereka tanam, karena tanaman yang dipilih tidak hanya satu jenis saja, maka penempatan dan luas lahan untuk tanamantanaman tersebut harus bisa mencapai hasil dan laba yang optimal, dan jumlah hasil panen yang sedikit sehingga mendapatkan laba yang sedikit pula.

Untuk mengatasi kendala-kendala yang sering dialami oleh petani, bidang matematika melalui Linear Programming (LP) dipastikan dapat memberikan solusi yang tepat. Pemrograman linear atau program linear adalah salah satu alat analisis dalam menyelesaikan problem riset operasional. Para peneliti mengatasi berbagai masalah penting melalui program linear (Higle dan Wallace, 2003). Sedangkan menurut Reveliotis (1997), pemrograman linier adalah suatu program matematika yang dari perspektif analitis berguna untuk mengidentifikasi suatu titik ekstrim (minimum atau maksimum) suatu titik pada fungsi $f\left(x \_1, x \_2, \ldots x \_n\right)$ yang selanjutnya memenuhi suatu set kendala misalnya $\mathrm{g}\left(\mathrm{x} \_1, \mathrm{x} \_2, \ldots \mathrm{x} \_\mathrm{n}\right) \geq \mathrm{b}$. Fungsi $\mathrm{f}$ disebut fungsi tujuan dan fungsi $\mathrm{g}$ disebut pembatas atau kendala. Kedua fungsi ini harus bersifat linier. Ditinjau dari segi aplikasi, program linier merupakan alat optimisasi yang dapat digunakan secara rasional oleh manejer dalam pengambilan keputusan secara teknologikal yang dibutuhkan dalam aplikasi tekno-sosioekonomi.

Adapun karakteristik pemrograman linear adalah sifat linearitas (Siringoringo, 2005). Sifat linearitas suatu kasus dapat ditentukan dengan menggunakan beberapa cara. Secara statistik, kita dapat memeriksa kelinearan dengan menggunakan grafik (diagram pencar). Secara teknis, linearitas ditunjukkan oleh adanya sifat proporsionalitas, additivitas, divisibilitas dan kepastian fungsi tujuan dan pembatas (kendala).

Menurut Winston (1995) serta Sarker dan Newton (2008), bahwa dalam menganalisis solusi optimal, peneliti menggunakan analisis sensitivitas untuk mengkaji bagaimana perubahan data mungkin mengubah solusi LP, misalnya bagaimana perubahan biaya produksi atau permintaan bisa mempengaruhi jadwal produksi. Karena perencanaan dalam skala yang besar, kerapkali mengandalkan pada jumlah data yang banyak dan mewakili estimasi terbaik, kemampuan untuk melaksanakan analisis sensitivitas. Dengan demikian, elemen data yang tidak pasti sering dianalisis dengan menggunakan analisis sensitivitas untuk menyelesaikan kembali pengaruh ketidakpastian. Penggunaan analisis sensitivitas untuk menghilangkan kekhawatiran tentang ketidakpastian menarik 
perhatian pada isu yang jarang muncul pada perkembangan model LP.

Penelitian ini membicarakan tentang model matematik optimasi penggunaan lahan pertanian dengan variabel ketersediaan air, ketersediaan bibit tanaman, ketersediaan pupuk, ketersediaan obat-obatan, ketersediaan tenaga kerja, luas lahan dan jenis tanaman yang akan ditanam. Jenis tanaman yang mempunyai nilai ekonomi (laba) relatif tinggi dan membutuhkan air yang relatif kecil akan keluar sebagai tanaman terpilih dengan luas lahan penanaman terbesar. Pemilihan tanaman dan luas lahan optimum untuk masing-masing tanaman terpilih dengan mendapatkan laba yang optimum dilakukan dengan LP. Penggunaan LP harus memperhitungkan harga-harga masukan dan keluaran produksi per hektar tanaman. Masukan produksi meliputi jasa air, sarana produksi (bibit, pupuk, dan obat-obatan), tenaga kerja, dan pajak tanah. Keluaran produksi adalah hasil panen dan nilai jual hasil panen tiap jenis tanaman.

Air dalam tanah juga dapat naik ke udara melalui tumbuh-tumbuhan. Peristiwa ini disebut evapotranspirasi. Banyaknya berbedabeda, tergantung dari kadar kelembaban tanah dan jenis tumbuhan. Transpirasi dan evaporasi dari permukaan tanah bersamasama disebut Evapotranspirasi atau Kebutuhan Air (Tjimpolo dan Kesumaningwati, 2009). Kebutuhan air suatu tanaman dapat didefinisikan sebagai "jumlah air yang diperlukan untuk memenuhi kehilangan air melalui evapotranspirasi (ETtanaman) tanaman yang sehat, tumbuh pada sebidang lahan yang luas dengan kondisi tanah yang tidak mempunyai kendala (kendala lengas tanah dan kesuburan tanah) dan mencapai potensi produksi penuh pada kondisi lingkungan tumbuh tertentu" (Soemarno, 2004).

Lahan pertanian dengan daerah hampir datar memiliki sifat di antaranya ialah pengairan baik, mudah diolah, ancaman erosi kecil, tidak terancam banjir. kemampuan menahan air baik, subur, dan respon terhadap pupuk. Pada lahan seperti ini sangat cocok untuk dijadikan sebagai lahan pertanian (Rahayu, 2004).

Pengolahan lahan pertanian dengan daerah hampir datar dilakukan dengan mengunakan teknik olah jalur dalam bentuk bedengan. Menurut Adimihardja dan Mappaona (2002), olah jalur merupakan cara pengolahan tanah secara terbatas dalam satu jalur yang akan ditanami. Cara ini umumnya dilakukan pada lahan kering. Selain membantu mengendalikan eorsi, olah jalur juga akan sangat membantu dalam menjaga kelembaban tanah, karena air hujan akan dapat bertahan dalam dalam jalur.

Olah jalur dibuat dengan menggali parit dengan lebar $30 \mathrm{~cm}$ dengan kedalam kira-kira $20 \mathrm{~cm}$. Arah jalur dibuat mengikuti garis kontur tanah dengan jarak antar jalur kira-kira 1 meter. Pemberian pupuk dapat dibenamkan dalam tanah dalam jalur. Pupuk yang diberikan dapat berupa pupuk kandang atau kompos, pupuk sebaiknya diberikan 3-4 minggu sebelum jalur ditanami, sehingga pupuk dapat hancur dan siap diserap tanaman.

Pengolahan lahan pertanian tidak lepas dari pengolahan tanah. Menurut Wikipedia (Anonymous, 2016), Pengolahan tanah adalah proses di mana tanah digemburkan dan dilembekkan dengan menggunakan bajak ataupun garu yang ditarik dengan berbagai sumber tenaga, seperti tenaga manusia, tenaga hewan, dan mesin pertanian (traktor). Melalui proses ini, kerak tanah teraduk, sehingga udara dan cahaya matahari menyentuh tanah lebih dalam dan meningkatkan kesuburannya. Sekalipun demikian, tanah yang sering digarap sering menyebabkan kesuburannya berkurang.

\section{METODE}

Model matematik optimasi pengelolaan lahan pertanian yang disusun untuk optimasi pengelolaan lahan pertanian. Penulis 
memfokuskan penelitian ini pada lahan pertanian di Desa Sinsingon, Kecamatan Passi Timur, Kabupaten Bolaang Mongondow, Provinsi Sulawesi Utara $\left(0^{\circ} 48^{\prime} \mathrm{N} \quad 124^{\circ} 24^{\prime} \mathrm{E}\right)$. Daerah tersebut merupakan dataran tinggi $( \pm 1000 \mathrm{~m} \mathrm{dpl})$ yang berada pada barisan pegunungan di pulau Sulawesi. Karena berada di daerah pegunungan yang suhunya berkisar antara $\llbracket 15 \rrbracket^{\wedge \circ} \mathrm{C}$ sampai dengan $\llbracket 25 \rrbracket^{\wedge \circ} \mathrm{C}$. Sinsingon sangat cocok untuk daerah pertanian. Jenis tanaman yang sering ditanam petani, antara lain tomat, bawang daun, sawi, kubis, kentang, jagung, kacang tanah.

Untuk mencapai tujuan penelitian, maka penelitian ini menggunakan metode action research. Metode ini dipilih karena dilakukan kajian (research) terhadap model-model pengembangan yang sudah dilaksanakan dan berdasarkan hasil kajian itu dirumuskan suatu model matematik awal tentang optimasi penggunaan lahan pertanian.

Kegiatan utama yang dilaksanakan ialah identifikasi keberadaan model pengembangan yang sudah ada dan penyusunan model matematik optimasi penggunaan lahan pertanian dengan memperhitungkan variabel ketersediaan air, ketersediaan bibit tanaman, ketersediaan pupuk, ketersediaan obat-obatan, ketersediaan tenaga kerja, luas lahan dan jenis tanaman yang akan ditanam.

\section{HASIL DAN PEMBAHASAN}

Dalam menyusun model awal menggunakan Model Linear Programming (LP), tim melakukan observasi lapangan untuk mengumpulkan data-data yang diperlukan. Data-data tersebut meliputi penyediaan air, penyediaan bibit tanaman, penyediaan pupuk, penyediaan obatobatan, penyediaan tenaga kerja, pajak tanah, hasil panen, dan harga jual. Dengan demikian, variabel keputusan untuk model ini didefinisikan sebagai berikut:

Misal $x_{i}$ : luas lahan optimum untuk jenis

tanaman ke- $i$ (ha)

$c_{i}$ : laba untuk jenis tanaman ke- $i(\mathrm{Rp} / \mathrm{ha})$

$a_{j i}$ : kebutuhan air pada bulan ke- $j$ untuk

jenis tanaman ke- $i\left(\mathrm{~m}^{3} / \mathrm{ha}\right)$

$b_{j}$ : kapasitas air yang tersedia pada bulan ke- $j\left(\mathrm{~m}^{3} / \mathrm{ha}\right)$

$d_{i}$ : kebutuhan bibit tanaman ke- $i$

(bibit/ha)

$e_{i}$ : jumlah bibit jenis tanaman ke- $i$ yang tersedia ( $\mathrm{kg} / \mathrm{ha})$

$f_{i}$ : kebutuhan pupuk jenis $k$ untuk

tanaman $\mathrm{ke}-i(\mathrm{~kg} / \mathrm{ha})$

$g_{i}$ : kebutuhan obat-obatan untuk tanaman ke- $i$ (liter/ha)

$h_{i}$ : kebutuhan tenaga kerja untuk tanaman ke- $i$ (orang/ha)

$k_{1}$ : total pupuk yang tersedia $(\mathrm{kg})$

$k_{2}$ : total obat-obatan yang tersedia (liter)

$k_{3}$ : total tenaga kerja yang tersedia

(orang)

$k_{4}$ : luas lahan total (ha)

$p$ : jumlah jenis tanaman

$q:$ umur tanaman (bulan)

$r:$ jumlah jenis pupuk

Untuk $i=1,2, \ldots, p ; j=1,2, \ldots, q$; dan $k=1,2, \ldots, r$

Model Linear Programming (LP) meliputi fungsi tujuan dan kendalakendala. Fungsi tujuannya adalah memaksimumkan laba petani yang berkaitan dengan masukan yang tersedia secara optimum. Dalam hal ini, laba yang diperoleh petani ialah jumlah hasi kali laba untuk jenis tanaman ke- $i$ dengan luas lahan optimum untuk jenis tanaman ke- $i$. Laba untuk jenis tanaman ke- $i$ diperoleh berdasarkan data-data masukkan, yaitu pendapatan kotor dari hasil panen dan pengeluaran meliputi biaya penyediaan air, biaya penyediaan bibit, biaya pupuk, biaya obat, upah tenaga kerja, dan pajak. Fungsi tujuan ini ditulis

$$
\text { Maksimumkan } z=\sum_{i=1}^{p} c_{i} x_{i}
$$


Sedangkan, kendala-kendalanya adalah penyediaan air, penyediaan bibit tanaman, penyediaan pupuk, penyediaan obat-obatan, penyediaan tenaga kerja dan luas lahan.

Kendala penyediaan air dalam hal ini ialah jumlah hasil kali kebutuhan air pada bulan ke- $j$ untuk jenis tanaman ke- $i$ dengan luas lahan optimum untuk jenis tanaman ke- $i$ tidak melebihi kapasitas air yang tersedia pada bulan ke- $j$, ditulis

$$
\sum_{i=1}^{p} a_{j i} x_{i} \leq b_{j}, \quad j=1,2, \ldots, q
$$

Kendala penyediaan bibit tanaman merupakan hasil kali kebutuhan bibit jenis tanaman ke- $i$ dengan luas lahan optimum untuk jenis tanaman ke- $i$ tidak melebihi jumlah bibit jenis tanaman ke- $i$ yang mampu disediakan oleh petani, ditulis

$$
d_{i} x_{i} \leq e_{i}, \quad i=1,2, \ldots, p
$$

Kendala penyediaan pupuk merupakan jumlah hasil kali kebutuhan pupuk untuk tanaman ke- $i$ dengan luas lahan optimum untuk jenis tanaman ke- $i$ tidak melebihi total pupuk yang tersedia, ditulis

$$
\sum_{i=1}^{p} f_{i} x_{i} \leq k_{1}
$$

Kendala penyediaan obat-obatan merupakan jumlah hasil kali kebutuhan obat-obatan untuk tanaman ke- $i$ dengan luas lahan optimum untuk jenis tanaman ke- $i$ tidak melebihi total obat-obatan yang tersedia, ditulis

$$
\sum_{i=1}^{p} g_{i} x_{i} \leq k_{2}
$$

Kendala penyediaan tenaga kerja merupakan jumlah hasil kali kebutuhan tenaga kerja untuk tanaman ke- $i$ dengan luas lahan optimum untuk jenis tanaman ke- $i$ tidak melebihi total tenaga kerja yang tersedia, ditulis

$$
\sum_{i=1}^{p} h_{i} x_{i} \leq k_{3}
$$

Kendala luas lahan merupakan jumlah luas lahan optimum untuk jenis tanaman ke- $i$ tidak melebihi luas lahan total, ditulis

$$
\sum_{i=1}^{p} x_{i} \leq k_{4}
$$

Kendala selanjutnya adalah batasan taknegatif, ditulis

$$
x_{i} \geq 0, \quad i=1,2, \ldots, p
$$

Selanjutnya, kendala (3), dapat disederhanakan menjadi

$$
x_{i} \leq \alpha_{i}, \quad i=1,2, \ldots, p
$$

dengan $\boldsymbol{\alpha}_{\boldsymbol{i}}=\boldsymbol{e}_{\boldsymbol{i}} / \boldsymbol{d}_{\boldsymbol{i}}$ atau merupakan hasil bagi kebutuhan bibit jenis tanaman ke- $i$ dengan jumlah bibit jenis tanaman ke$i$ yang mampu disediakan oleh petani.Oleh karena itu, kendala baru (9) dapat digabungkan dengan kendala taknegatif (8), dan ditulis

$$
0 \leq x_{i} \leq \alpha_{i}, \quad i=1,2, \ldots, p
$$

Dengan demikian, model model awal dapat ditulis

Maksimumkan

$$
z=\sum_{i=1}^{p} c_{i} x_{i}
$$

dengan kendala-kendala:

$$
\begin{gathered}
\sum_{i=1}^{p} a_{j i} x_{i} \leq b_{j}, \quad j=1,2, \ldots, q \\
\sum_{\substack{p=1 \\
p}}^{p} f_{i} x_{i} \leq k_{1} \\
\sum_{i=1}^{p} g_{i} x_{i} \leq k_{2} \\
\sum_{i=1}^{p} h_{i} x_{i} \leq k_{3} \\
\sum_{i=1}^{p} x_{i} \leq k_{4} \\
0 \leq x_{i} \leq \alpha_{i}, \quad i=1,2, \ldots, p
\end{gathered}
$$




\section{PENUTUP}

\section{Kesimpulan}

Model awal yang disusun berdasarkan Model Linear Programming (LP) dengan data-data masukan dapat ditulis sebagai berikut:

Variabel Keputusan:

Misal $x_{i}$ : luas lahan optimum untuk jenis tanaman ke- $i$ (ha)

$c_{i}$ : laba untuk jenis tanaman ke- $i$ (Rp/ha)

$a_{j i}$ : kebutuhan air pada bulan ke- $j$ untuk jenis tanaman ke- $i$ $\left(\mathrm{m}^{3} / \mathrm{ha}\right)$

$b_{j}$ : kapasitas air yang tersedia pada bulan ke- $j\left(\mathrm{~m}^{3} / \mathrm{ha}\right)$

$d_{i}$ : kebutuhan bibit tanaman ke- $i$ (bibit/ha)

$e_{i}$ : jumlah bibit jenis tanaman ke- $i$ yang tersedia $(\mathrm{kg} / \mathrm{ha})$

$f_{i}$ : kebutuhan pupuk jenis $k$ untuk tanaman $\mathrm{ke}-i(\mathrm{~kg} / \mathrm{ha})$

$g_{i}$ : kebutuhan obat-obatan untuk tanaman ke- $i$ (liter/ha)

$h_{i}$ : kebutuhan tenaga kerja untuk tanaman ke- $i$ (orang/ha)

$k_{1}$ : total pupuk yang tersedia $(\mathrm{kg})$

$k_{2}$ : total obat-obatan yang tersedia (liter)

$k_{3}$ : total tenaga kerja yang tersedia (orang)

$k_{4}$ : luas lahan total (ha)

$p:$ jumlah jenis tanaman

$q:$ umur tanaman (bulan)

$r:$ jumlah jenis pupuk

Untuk $i=1,2, \ldots, p ; j=1,2, \ldots, q$; dan $k=1,2, \ldots, r$

Fungsi Tujuan:

$$
\text { Maksimumkan } z=\sum_{i=1}^{p} c_{i} x_{i}
$$

Kendala-kendala:

$$
\sum_{i=1}^{p} a_{j i} x_{i} \leq b_{j}, \quad j=1,2, \ldots, q
$$

$$
\begin{gathered}
\sum_{i=1}^{p} f_{i} x_{i} \leq k_{1} \\
\sum_{\substack{i=1 \\
p}}^{p} g_{i} x_{i} \leq k_{2} \\
\sum_{\substack{i=1 \\
p}}^{p} h_{i} x_{i} \leq k_{3} \\
\sum_{i=1}^{p} x_{i} \leq k_{4} \\
0 \leq x_{i} \leq \alpha_{i}, \quad i=1,2, \ldots, p
\end{gathered}
$$

\section{DAFTAR PUSTAKA}

Adimihardja, A., Mappaona, A.S. (2002). Teknologi Pengelolaan Lahan Kering Menuju Pertanian Produktif dan Ramah Lingkungan. Pusat Penelitian dan Pengembangan Tanah dan Agroklimat. Bogor.

Darmajana. D.A. (1987). Optimasi Penggunaan Lahan Pertanian dengan Program Linear. Jakarta: Teknologi Indonesia.

Higle, J.L. dan Wallace. S.W. (2003). Sensitivity Analysis and Uncertainity in Linear Programming. INFORMS. Vol. 33 No. 4. pp. 5360.

Rahayu, S. (2004). Pertanian Ekologis: Keuntungan dan Kendalanya. ICRAF-SEA: Bogor. Diambil dari http://www.leisa.info/index.

Reveliotis. Spyros. (1997). An Introduction to Linear Programming and the Simplex Algorithm. Diambil dari http://www.isye.gatech.edu/ spyros/L P/LP.html diakses tanggal 10 Februari 2015

Sarker R.A. dan Newton C.S. (2008). Optimization modelling : a practical introduction. New York: CRC Press.

Siringringo. H. (2005). Seri Teknik Riset Operasional. Pemrograman Linear. Yogyakarta: Graha Ilmu. 
J. U. L. Mangobi ${ }^{1}$, S. M. Salajang2, Jurnal Sains dan Teknologi, Universitas Negeri Manado \& O. T. Sambuaga ${ }^{3}$ http://ejournal.unima.ac.id/index.php/efrontiers

Soemarno. (2004). Pengelolaan Air Tanah Bagi Tanaman. Malang: Universitas Brawijaya.

Tjimpolo. Z.L. dan Kesumaningwati. R. (2009). Evapotranspirasi dan Beberapa Rumus Perhitungannya. Diambil dari http://tjimpolo.blogg.com diakses tanggal 10 Februari 2015

Winston. W.L. (1995). Introduction to Mathematical Programming; Aplication and Algorithms. Boston: PWS-Kent Publishing Company

\section{RIWAYAT HIDUP PENULIS}

James Uriel Livingstone Mangobi, S.Pd., M.Si.

Lahir di Dagho, 15 Juli 1977. Staf pengajar di Jurusan Matematika FMIPA Unima. Studi S1 Pendidikan Matematika Universitas Negeri Manado lulus tahun 2001; S2 Matematika Terapan Institut Pertanian Bogor lulus tahun 2011. 